\title{
GABA and Dopamine Act Directly on Melanotropes of Xenopus to Inhibit MSH Secretion ${ }^{1}$
}

\author{
B. M. L. VERBURG-VAN KEMENADE, B. G. JENKS \\ AND A. G. J. DRIESSEN \\ Department of Zoology, Faculty of Science, Catholic University \\ Toernooiveld, 6525 ED Nijmegen, The Netherlands
}

\begin{abstract}
VERBURG-VAN KEMENADE, B. M. L., B. G. JENKS AND A. G. J. DRIESSEN. GABA and dopamine act directly on melanotropes of Xenopus to inhibit MSH secretion. BRAIN RES BULL 17(5) 697-704, 1986.-The release of melanophore stimulating hormone (MSH) from the pars intermedia of the amphibian Xenopus laevis is regulated by multiple factors of hypothalamic origin. The aim of this study was to determine if potential secretagogues function through a direct action on the melanotrope cell. For this purpose an in vitro superfusion system containing isolated melanotropes (cell suspension) was utilized. The viability of the cells in suspension was tested by examining their ability to synthesize, process and release pro-opiomelanocortin (POMC) related peptides. All biosynthetic functions appeared normal, with the exception that the isolated melanotropes are unable to N-terminally acetylate MSH. Release of immunoreactive-MSH from these cells was shown to be $\mathrm{Ca}^{2+}$-dependent, and high $\mathrm{K}^{+}$stimulated release. Both the neurotransmitters dopamine and $\gamma$-aminobutyric acid (GABA), which are thought to be physiologically important MSH-release inhibiting factors, were shown to inhibit MSH release from isolated melanotropes. Dopamine appeared to function through a dopamine D2 type receptor mechanism while for GABA, both a GABAa and GABAb receptor mechanism are involved.
\end{abstract}

$\begin{array}{llll}\text { Melanotropes Melanophore stimulating hormone } & \alpha M S H & \text { Desacetyl- } \alpha \text { MSH Acetylation } \\ \text { Pro-opiomelanocortin Amphibian Dopamine } & \text { GABA } & \text { Receptor characterization }\end{array}$

THE regulation of dispersion of the black pigment melanin in dermal melanophores of amphibians is an example of a neuroendocrine reflex [1]. Most amphibians, when placed on a black background, release melanophore stimulating hormone (MSH) from the pars intermedia of the pituitary gland and consequently there is a darkening of the skin. While it is thought that central integration of the environmental input (color of background) would play an important role in determining the rate of MSH secretion, a consideration of the complexity of the innervation of the pars intermediate lobe itself may be an important factor in this integration. For example, in the aquatic toad Xenopus laevis, a dopaminergic system [24,25], an adrenergic system [9] and a GABAergic system [29] have been described within the pars intermedia. Moreover it has been shown that both dopamine $[10,14]$ and $\alpha$-adrenergic receptor agonists [28] as well as GABA [29] inhibit MSH release from incubated neurointermediate lobes of this species. In studies with intact neurointermediate lobe tissue the question arises if the secretagogues affect MSH release through an action directly on the melanotrope cells. The alternative is an indirect action, such as GABA induced release of dopamine, a phenomenon known to occur in the central nervous system [23]. To determine to what extent the pars intermedia melanotrope cell might be involved in integrating signals from the diverse neuronal systems within the neurointermediate lobe tissue, we are examining the effects of secretagogues on the release of immunoreactive MSH from isolated superfused melanotrope cells. The present study describes our preparation of melanotrope cell suspension and shows that both dopamine and GABA act directly on these cells.

\section{METHOD}

\section{Animals}

Xenopus laevis were bred and reared in our aquatic facility. Prior to the experiment the animals were kept for four weeks on a black background under constant illumination at $22^{\circ} \mathrm{C}$.

\section{Preparation of Cell Suspension}

Neurointermediate lobes were extirpated, rinsed in incubation medium (IM) containing $112 \mathrm{mM} \mathrm{NaCl}, 2 \mathrm{mM} \mathrm{KCl}, 2$

"This refereed paper was submitted in connection with a Symposium on "Multineuronal Control of the Intermediate Lobe of the Pituitary" as part of the Sixth European Winter Conference on Brain Research at Avoriaz, France, March 9-15, 1986. The Symposium was organized by H. Vaudry and G. Pelletier and supported by the University of Rouen (France), UCB Bioproducts Laboratories (Brussels, Belgium) and SANOFI (Toulouse, France). 


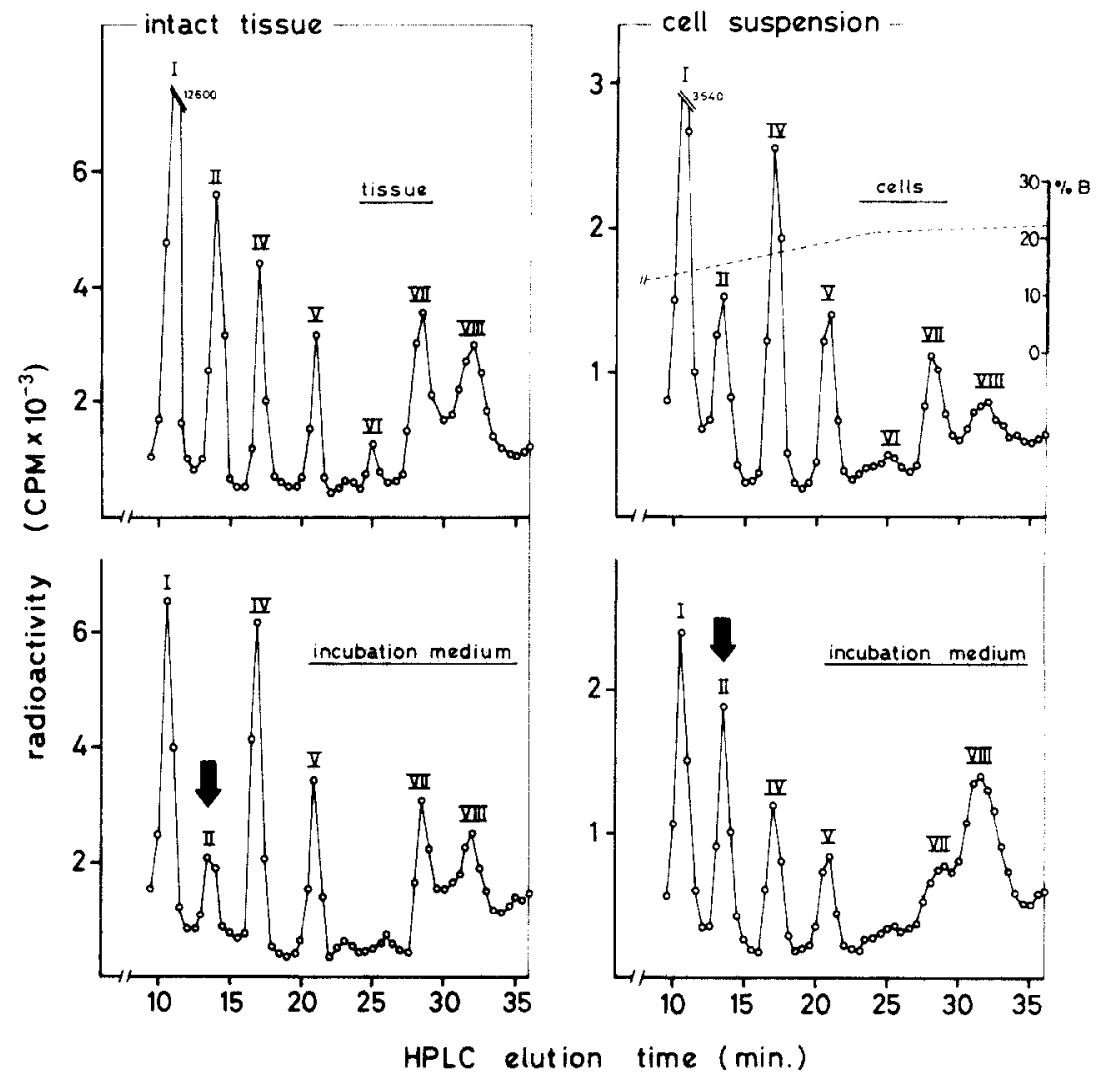

FIG. 1. Comparison of viability of neurointermediate lobes and isolated intermediate lobe melanotropes of Xenopus laevis. Both intact tissue and cell suspension were given a $1 \mathrm{hr}$ pulse-incubation in $\left[{ }^{3} \mathrm{H}\right]$ lysine followed by a $3 \mathrm{hr}$ chase incubation in medium containing L-lysine. Tissue extract, cell extract and chase incubation media were submitted to HPLC. The elution gradient (\% secondary solvent, B) is given. Characterization of the newly synthesized peptides (numbered I-VIII) has been reported earlier [19] and is summarized in the Results section. Arrows indicate a major difference between intact tissue and cell suspension, namely the relatively high contribution of product II to the incubation medium of the cell suspension. This product has been previously identified as desacetyl- $\alpha \mathrm{MSH}$.

$\mathrm{mM} \mathrm{CaCl} \cdot 2 \mathrm{H}_{2} \mathrm{O}, 2 \mathrm{mg} / \mathrm{ml}$ glucose, $15 \mathrm{mM}$ Hepes $\mathrm{pH} 7.38$. The medium was preaerated with carbogen. The tissue was subsequently transferred to $1.5 \mathrm{ml}$ IM to which was added 3 $\mathrm{mg} / \mathrm{ml}$ bovine serum albumin (BSA, Sigma Fraction V), 1 $\mathrm{mg} / \mathrm{ml}$ collagenase (Sigma) and $1.25 \mathrm{mg} / \mathrm{ml}$ dispase (grade II lyophilisat, Boehringer) and incubated for $1 \mathrm{hr}$ in a shaking water bath at $22^{\circ} \mathrm{C}$. After centrifugation $\left(10 \mathrm{~min}, 200 \mathrm{~g}, 22^{\circ} \mathrm{C}\right)$ the pellet was carefully suspended in $1.5 \mathrm{ml} \mathrm{Ca-free} \mathrm{medium}$ to which $3 \mathrm{mg} / \mathrm{ml} \mathrm{BSA}$ and $0.4 \mathrm{mg} / \mathrm{ml}$ ETDA were added. The suspension was centrifuged, resuspended in $1.5 \mathrm{ml} \mathrm{Ca-}$ free medium with $3 \mathrm{mg} / \mathrm{ml}$ BSA and $1.25 \mathrm{mg} / \mathrm{ml}$ dispase and incubated for $30 \mathrm{~min}$ at $22^{\circ} \mathrm{C}$ with shaking. Tissue fragments were then allowed to settle and the supernatant containing melanotropes in suspension (fraction 1) was saved. The fragments were rinsed and treated with Ca-free medium containing BSA and dispase, and centrifuged for $3 \mathrm{~min}$ at $200 \mathrm{~g}$ over a nylon filter (pore size $0.15 \mathrm{~mm}$ ). The collected cell suspension (fraction 2) was combined with fraction 1 and centrifuged ( $10 \mathrm{~min}, 200 \mathrm{~g}$ ). The pellet was rinsed and resuspended first in medium containing $3 \mathrm{mg} / \mathrm{ml} \mathrm{BSA}, 0.8 \mathrm{mg} / \mathrm{ml}$ EDTA. Finally it was centrifuged and suspended in IM with $0.3 \mathrm{mg} / \mathrm{ml}$ BSA. All glassware was siliconized.
The percentage of cell death was established with trypan blue and cell yield was estimated with a haemocytometer. Pars nervosa remnants were traced by cytochemical staining with anti-oxytocin.

\section{Pulse-Chase Incubation of Neurointermediate Lobe Tissue or Isolated Melanotropes}

Neurointermediate lobe tissue was extirpated, rinsed in IM and given a pulse incubation in $200 \mu \mathrm{l}$ IM containing 40 $\mu \mathrm{Ci}\left[{ }^{3} \mathrm{H}\right]$ lysine $(75 \mathrm{Ci} / \mathrm{mmol}$, Amersham), on a shaking water bath at $22^{\circ} \mathrm{C}$. Tissue was rinsed in IM and chase incubated in $200 \mu \mathrm{l}$ medium containing L-lysine $(2 \mathrm{mM})$. It was then homogenized in $500 \mu$ ice-cold $0.1 \mathrm{~N} \mathrm{HCl}$ in a glass homogenizer and centrifuged $\left(10 \mathrm{~min}, 10,000 \mathrm{~g}, 4^{\circ} \mathrm{C}\right)$. The supernatant was stored at $-20^{\circ} \mathrm{C}$ before it was submitted to high performance liquid chromatography (HPLC) for separation of peptides. The incubation medium was acidified with $20 \mu l 1 \mathrm{~N} \mathrm{HCl}$ and kept at $-20^{\circ} \mathrm{C}$ before chromatography.

For pulse-chase analysis of cell suspensions, the cellpellets were resuspended in $200 \mu \mathrm{I}$ IM. Pulse incubation was started by addition of $100 \mu \mathrm{I} \mathrm{IM}$, containing $40 \mu \mathrm{Ci}$ 


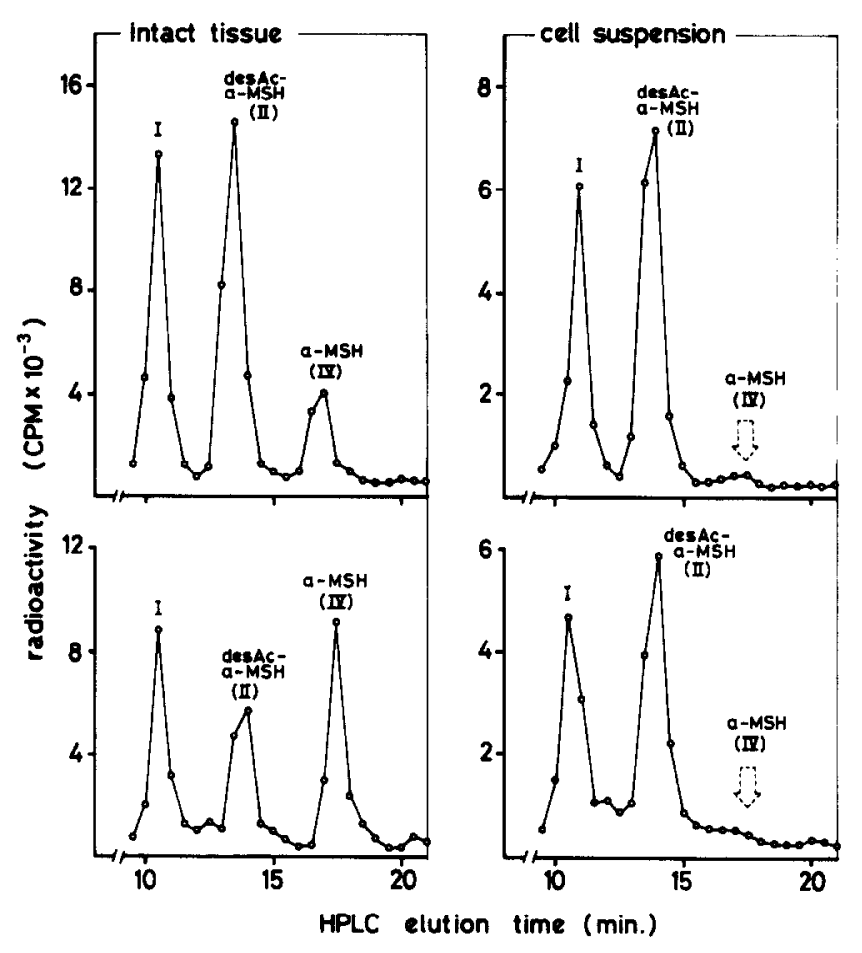

FIG. 2. Analysis of newly synthesized desacetyl- $\alpha$ MSH (desAc$\alpha M S H)$ and $\alpha M S H$ present in and released from intact neurointermediate lobes and isolated intermediate lobe melanotropes of Xenopus laevis. Neurointermediate lobes or the cell suspension were given a pulse incubation in [ $\left.{ }^{3} \mathrm{H}\right]$ tryptophan and a $3.5 \mathrm{hr}$ chase incubation in medium containing L-tryptophan. Lobe extracts, cell extracts, and chase incubation media were then submitted to HPLC. The HPLC elution gradient is identical to that given in Fig. 1. Tissue and cell analyses are given in the upper profiles; analyses of incubation media are given in the lower profiles. Tryptophan labeled product II is desacetyl- $\alpha M S H$, product IV is $\alpha M S H$ and product I represents the co-eluting peptides $\alpha \mathrm{MSH}$ and $\beta \mathrm{MSH}$.

$\left[{ }^{3} \mathrm{H}\right]$ lysine. Cells were subsequently centrifuged ( $10 \mathrm{~min}, 200$ $\mathrm{g}, 22^{\circ} \mathrm{C}$ ) and the pellet resuspended for chase-incubation in $500 \mu \mathrm{l}$ IM with L-lysine $(2 \mathrm{mM})$. Following this incubation cells were centrifuged, resuspended in $500 \mu 10.1 \mathrm{~N} \mathrm{HCl}$ and homogenized. Cell debris was removed by centrifugation (10 $\min , 10,000 \mathrm{~g}, 4^{\circ} \mathrm{C}$ ) and the supernatant was submitted to HPLC. Chase medium was acidified with $20 \mu 11 \mathrm{~N} \mathrm{HCl}$ before submission to HPLC. All incubation times are given in the figure legends.

A similar experiment to that described above was conducted with $40 \mu \mathrm{Ci}\left[{ }^{3} \mathrm{H}\right]$ tryptophan $(52 \mathrm{Ci} / \mathrm{mmol}$, Amersham) as label. In this experiment each HPLC fraction was divided; part was used for analysis of radioactive peptides and part was submitted to radioimmunoassay for analysis of $\alpha \mathrm{MSH}$ related peptides.

\section{HPLC Analysis of Radioactive Peptides}

Peptides were separated on a sperisorb 10 ODS column (Chrompack, Middelburg, the Netherlands). The primary solvent was $0.5 \mathrm{M}$ formic acid/0.14 M pyridine, pH 3.0 (A) and elution was accomplished with a gradient of n-propanol
(B). The elution profile is indicated in Fig. 1. Fractions of 0.5 min were collected, $4 \mathrm{ml}$ of scintillation fluid (Packard 199) were added for subsequent determination of radioactivity in a liquid scintillation counter.

\section{Radioimmunoassay of $\alpha \mathrm{MSH}$}

The C-terminal directed antiserum to $\alpha \mathrm{MSH}$ was produced and characterized by Vaudry et al. [27]. It has equal reactivity to $\alpha \mathrm{MSH}$ and desacetyl- $\alpha \mathrm{MSH}$. Bound and unbound MSH were separated by precipitation with polyethyleneglycol (7.5\%). Sensitivity threshold of the assay is 5 pg.

\section{Superfusion of Isolated Melanotropes}

Cells were suspended in a small volume of incubation medium and loaded in a $50 \mu$ l superfusion chamber with a millipore $0.45 \mu \mathrm{m}$ filter (type HA) at the outlet to support a layer of biogel $\mathbf{P} 2$ (Biorad). Following loading the chamber was filled with biogel. Medium was pumped with a peristaltic pump at a rate of $1.5 \mathrm{ml} / \mathrm{hr}$ and $7.5 \mathrm{~min}$ fractions were collected in $100 \mu \mathrm{l}$ ice-cold $0.1 \mathrm{~N} \mathrm{HCl}$. Fractions were stored at $-20^{\circ} \mathrm{C}$ before submission to radioimmunoassay. After an equilibration period of approximately $1 \mathrm{hr}$ the effect of calcium-free medium with $0.5 \mathrm{M}$ EGTA, or high $\mathrm{K}^{+}$(osmolarity maintained by addition of $\mathrm{NaCl}$ ) was established by giving $15 \mathrm{~min}$ pulses of the modified media. For comparative purposes the effect of high $\mathrm{K}^{+}$on $\mathrm{MSH}$ release from intact neurointermediate lobe tissue was investigated. Lobes were placed in a $10 \mu \mathrm{l}$ superfusion chamber and superfusion was performed as described earlier [28,29].

The effect of dopamine and/or GABA was investigated by giving $15 \mathrm{~min}$ pulses of these neurotransmitters to the superfused melanotropes. In additional experiments the dopamine D2-receptor antagonist sulpiride (Delagrange), the GABAa agonists homotaurine (kindly provided by Dr. Maggi, Italy) and isoguvacine (Cambridge Research Biochemicals) and the GABAb agonist baclofen (Ciba Geigy) were used.

\section{RESULTS}

\section{Analysis of Cell Suspension Viability}

Average yield of cells was 18,000 per neurointermediate lobe. Microscopical analysis showed that the suspension consisted for the most part of individual cells with occasional cohesion of two or three cells. Percentage of cell death was estimated to be $12 \%$. As judged from the anti-oxytocin cytochemical staining, the cell suspension was free of neural lobe fragments. The oxytocin positive material remained as intact tissue on top of the nylon filter.

Radiolabeled lysine was a convenient label for our initial biosynthetic analysis because this amino acid is present in all POMC-related peptides products of Xenopus melanotropes $[16,19]$. Shown in Fig. 1 are the results of pulse-chase analysis of intact neurointermediate lobe tissue and the cell suspension. The HPLC resolved peptides have been characterized earlier [19] to be: I, $\gamma$ MSH; II, desacetyl- $\alpha$ MSH; IV, coeluting peptides $\alpha M S H$ and a form of corticotropin-like intermediate peptide (CLIP), designated CLIP I; V, a second form of CLIP, designated CLIP II; VI, unidentified; VII/VIII, peptides immunologically related to mammalian Bendorphin and designated endorphin-like peptides. These earlier studies failed to identify $\beta$ MSH. Sequence determination of Xenopus POMC-cDNA has revealed that $\beta M$ MS is a potential biosynthetic product of Xenopus neurointer- 


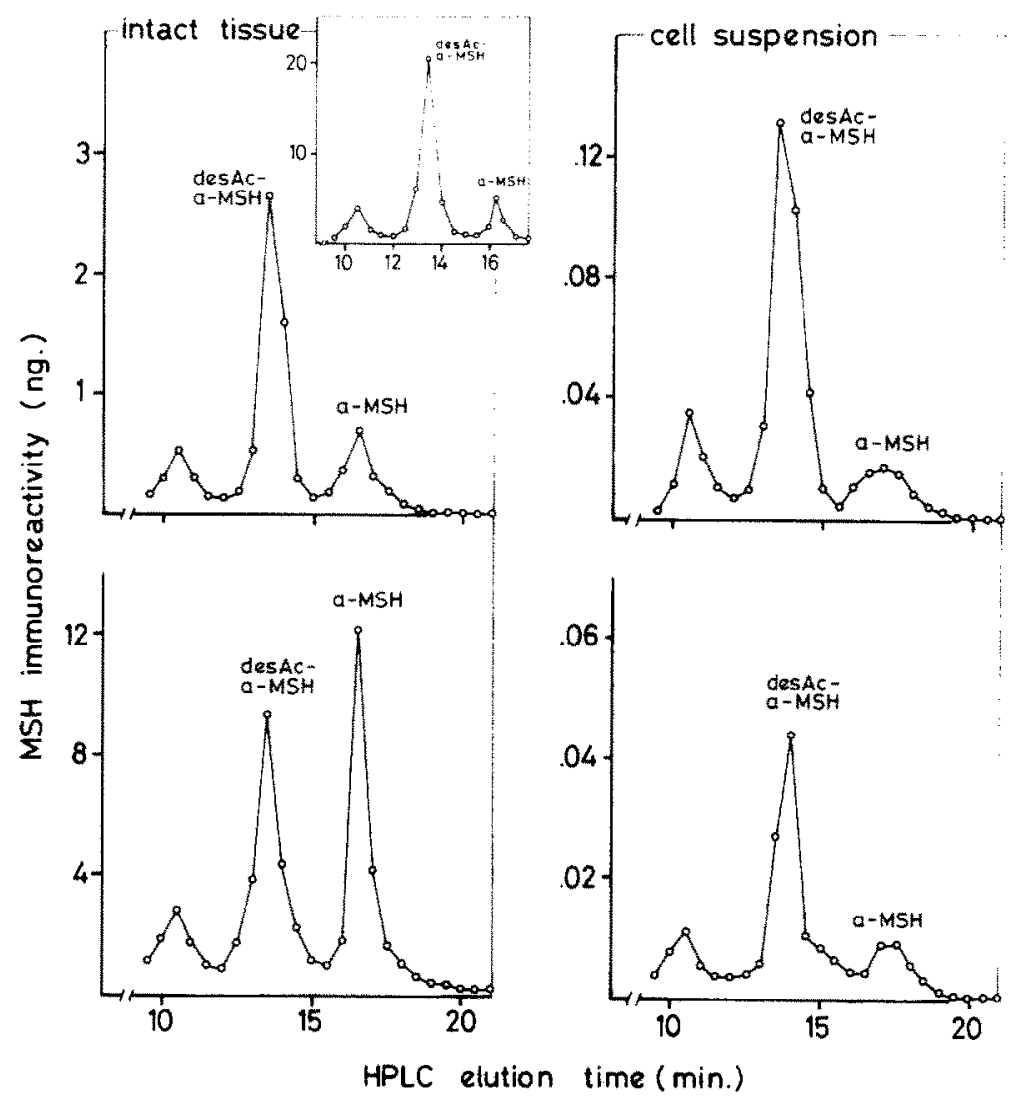

FIG. 3. Analysis of immunoreactive MSH present in and released from intact neurointermediate lobe and isolated intermediate lobe melanotropes of Xenopus laevis. Data is derived from the same experiment as that shown in Fig. 2; a portion of each HPLC fraction was submitted to radioimmunoassay. Tissue and cell analyses are given in the upper profiles, media analyses in the lower profiles. The peak eluting between 10 and 11 minutes probably reflects a slight cross-reactivity of the antiserum to $\gamma \mathrm{MSH} / \beta \mathrm{MSH}$. Insert: HPLC analysis of tissue extract from an unincubated neurointermediate lobe.

mediate lobes [16], and indeed our subsequent analysis has shown that newly synthesized $\beta$ MSH co-elutes with $\gamma$ MSH in a peak 1 (manuscript in preparation). Co-elution of two peptides may account for the relatively high CPM value associated with peak $I$.

The HPLC profile of newly synthesized lysine labeled peptides produced by and released from cell suspensions is very similar to that displayed by intact tissue with the notable exception of the relatively high contribution of product 11 (desacetyl- $\alpha$ MSH) to the incubation medium of the cell suspension (Fig. 1). To examine the biosynthesis of $\alpha \mathrm{MSH}$ this experiment was repeated with $\left[{ }^{3} \mathrm{H}\right]$-tryptophan as label (the CLIP peptide co-eluting with $\alpha$ MSH lacks tryptophan). The major tissue form of the newly synthesized $\alpha \mathrm{MSH}$ related peptides is desacetyl- $\alpha \mathrm{MSH}$, although some $\alpha \mathrm{MSH}$ is associated with the tissue (Fig. 2). The intact tissue secretes both desacetyl- $\alpha$ MSH and $\alpha$ MSH, but $\alpha$ MSH now makes a major contribution to the HPLC profile. For the cell suspension newly synthesized desacetyl- $\alpha$ MSH is both the major cellular and secretory form of $\alpha$ MSH related peptides. There is virtually no newly synthesized $\alpha \mathrm{MSH}$ present (Fig. 2).

\section{Analysis of Immunoreactive $\alpha M S H$ Related Peptides}

Desacetyl- $\alpha$ MSH was the major form of immunoreactive MSH associated with both tissue (Fig. 3, left) and isolated cells (Fig. 3, right). Separate experiments $(n=3)$ showed that the percentage of non-acetylated $\alpha \mathrm{MSH}$ was $77 \pm 1.7 \%$ in intact tissue and $88 \pm 3.0 \%$ in isolated melanotropes.

HPLC analysis of immunoreactive MSH from incubation medium of intact tissue shows that desacetyl- $\alpha \mathrm{MSH}$ and aMSH make an approximately equal contribution to the medium (Fig. 3, left). There is apparently a reduction of tissue stores of MSH during in vitro incubation, indicated by the fact that the amount of MSH in the tissue of the incubated lobe is only about $10 \%$ of that found in an unincubated neurointermediate lobe (Fig. 3 , insert). Relative to intact tissue, the cell suspension had a low level of immunoreactive MSH (Fig. 3, right). These cells released predominantly the non-acetylated form of $\alpha \mathrm{MSH}$ (Fig. 3).

\section{MSH Release From Superfused Melanotropes}

Superfused melanotropes had a tendency to show a slop- 


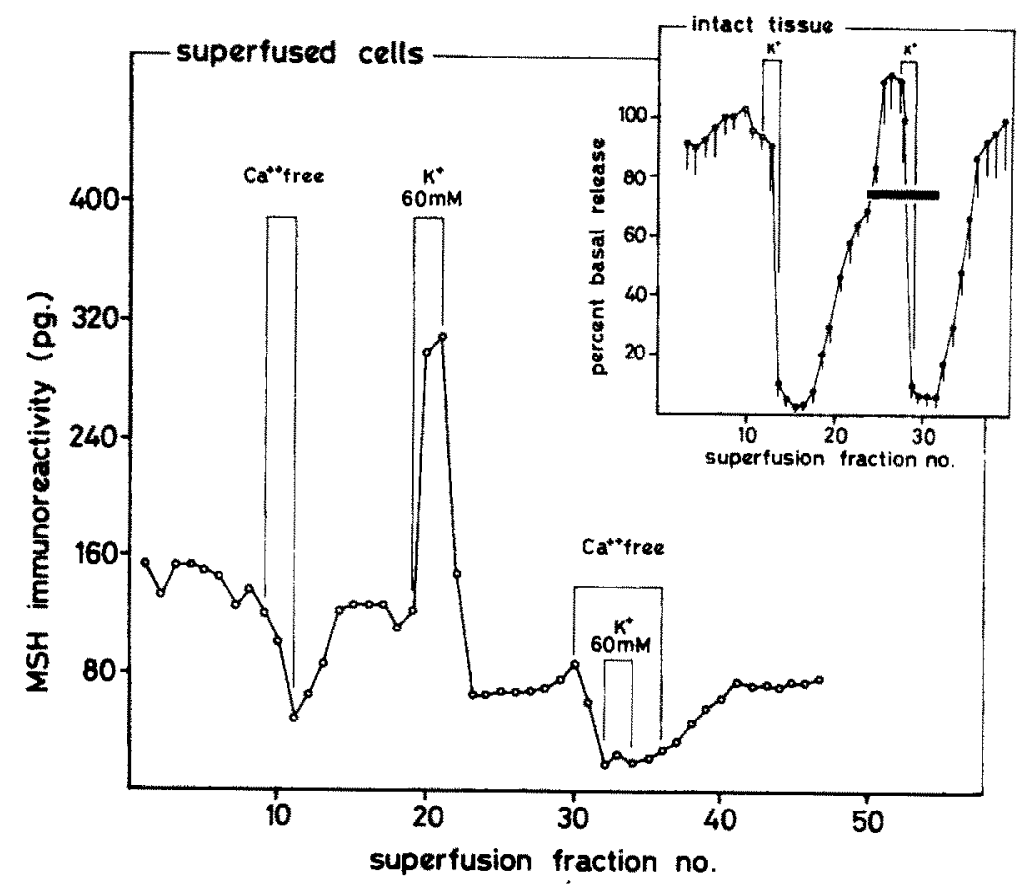

FIG. 4. The release of immunoreactive MSH from superfused melanotropes of Xenopus laevis. Superfusion fractions were submitted to radioimmunoassay for $\alpha M S H$. Short pulses (15 min) of Ca-free medium (containing $0.5 \mathrm{mM}$ EGTA), medium containing $60 \mathrm{mM} \mathrm{K}$, or a combination of the two treatments were given as indicated in the figure. Insert: The effect of $60 \mathrm{mM} \mathrm{K}^{+}$on the release of $\mathrm{MSH}$ from intact neurointermediate lobes. Black bar indicates those fractions where sulpiride $\left(10^{-3} \mathrm{M}\right)$ was included in the superfusion medium. Results are expressed as percent basal release $(-\mathrm{SEM}, \mathrm{n}=4) ; 100 \%$ basal release was defined in each experiment as the average amount of MSH in the three fractions preceding the first pulse of $\mathrm{K}^{+}$(indicated by open circles).

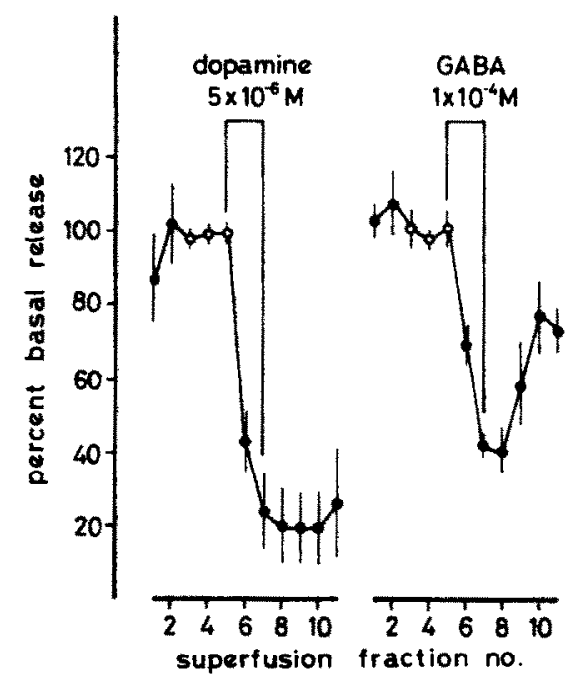

FIG. 5. The effect of dopamine and GABA on the release of immunoreactive MSH from superfused melanotropes of Xenopus laevis. Results are expressed as percent basal release $( \pm S E M, n=4)$. Open cincles indicate those fractions used to determine $100 \%$ basal release. Superfusion conditions are described in Fig. 4.

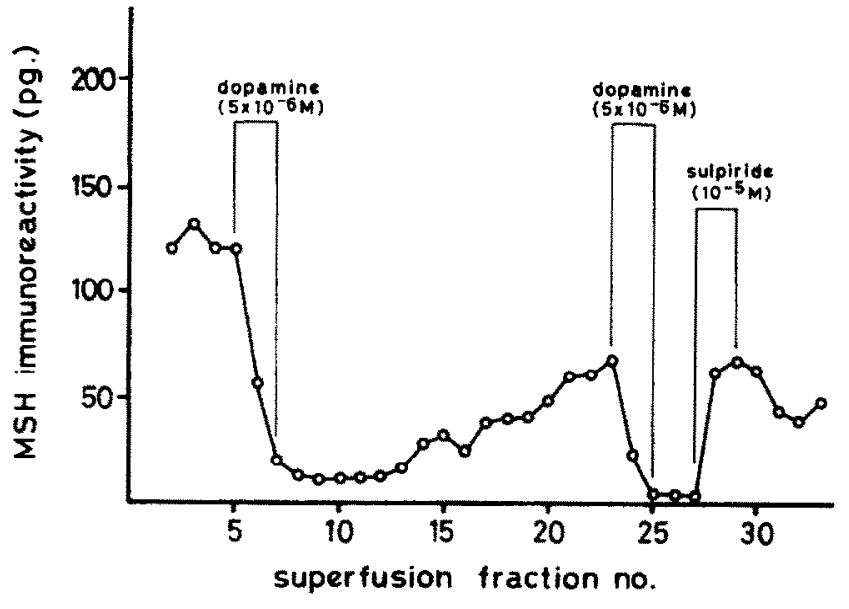

FIG. 6. Effect of dopamine and the dopamine D2-receptor antagonist sulpiride on the release of immunoreactive MSH from superfused melanotropes of Xenopus laevis. Superfusion conditions are described in Fig. 4. 


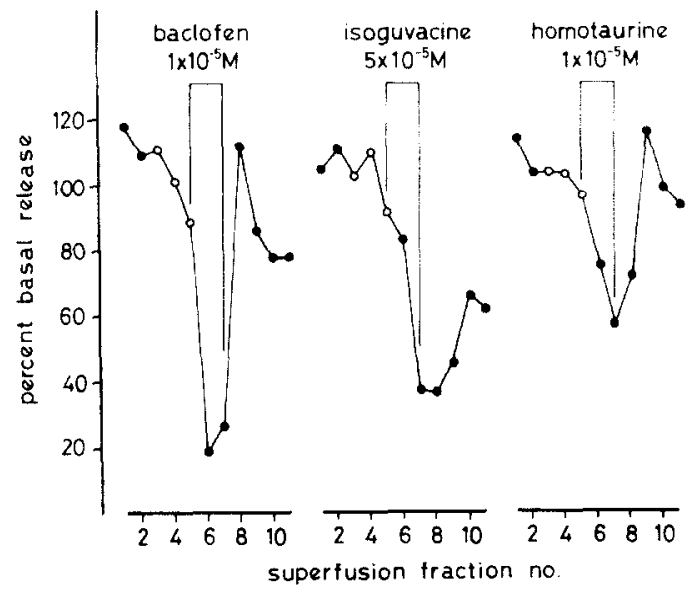

FIG. 7. The effect of GABA receptor agonists on the release of immunoreactive MSH from superfused melanotropes of Xenopus laevis. Baclofen is a GABAb receptor agonist and isoguvacine and homotaurine are GABAa receptor agonists. Superfusion conditions are described in Fig. 4. Open circles indicate those fractions used to determine $100 \%$ basal level of release.

ing base-line of MSH release (e.g., Fig. 1). Also, the rate of release of MSH could vary widely between different cell suspension preparations. The differences in absolute value of MSH released in different experiments precluded averaging of results and therefore, where we wished to combine results from more than one experiment, they are expressed as a percentage of the basal rate of release (e.g., Fig. 5). In this case the average level of MSH in the three superfusion fractions immediately preceding the pulse of secretagogue was defined as $100 \%$ basal release for each experiment, and within each experiment all MSH values in superfusion fractions were then expressed relative to this basal value.

The rate of release of $\alpha \mathrm{MSH}$ from superfused cells was reduced by giving a short pulse of $\mathrm{Ca}^{2+}$-free medium (Fig. 4). A pulse with medium containing $60 \mathrm{mM} \mathrm{K} \mathrm{K}^{+}$resulted in a dramatic increase in the amount of MSH found in the superfusion fractions. This contrasts sharply with the response of intact tissue to $60 \mathrm{mM} \mathrm{K}^{+}$(Fig. 4, insert), where the amount of MSH in the superfusion fractions decreases. Sulpiride had no effect on this $\mathrm{K}^{+}$induced inhibition of MSH release.

Both dopamine and GABA caused a clear reduction if the amount of MSH released to the superfusion medium (Fig. 5). The dopamine induced inhibition was very prolonged (Fig. 6), but could be reversed by sulpiride, a dopamine D2receptor agonist. Both the $\mathrm{GABAb}$ receptor agonist baclofen and the GABAa receptor agonists isoguvacine and homotaurine inhibited MSH secretion from superfused melanotropes (Fig. 7).

\section{DISCUSSION}

The results of our biosynthetic studies indicate that the cell suspension constitutes a viable population of melanotropes. The only impairment we could detect was their inability to acetylate desacetyl- $\alpha$ MSH to form $\alpha \mathrm{MSH}$. This observation is interesting in that it has been shown that acetylation of MSH in the pars intermedia of Xenopus laevis is associated with the secretory process [18]. The failure of isolated cells to acetylate MSH may reflect the close association of this event with exocytosis. Possibly, the acetylation system is sensitive to minor perturbations of membrane structure or alterations in ionic environment. Another possible reason for the inability of isolated melanotropes to acetylate desacetyl- $\alpha$ MSH would be that the isolated melanotropes lack a physiological signal, which is necessary for the onset of the acetylation process. In separate experiments we have found that the degree of acetylation is probably regulated according to the background color to which the animal is adapted. The secretion-associated acetylation of intact tissue is reflected in the present results by the enhanced contribution of both newly synthesized $\alpha \mathrm{MSH}$ and immunoreactive $\alpha \mathrm{MSH}$ to the HPLC profile of incubation media relative to their contribution to the corresponding tissue profiles. The results indicate that while a small amount of intracellular acetylation is occurring, the non-acetylated peptide remains the major newly synthesized and immunoreactive tissue form of $\alpha \mathrm{MSH}$. In contrast, pulse-chase analysis with rat and mouse intermediate lobe tissue or cells show that desacetyl- $\alpha$ MSH is acetylated immediately following its biosynthesis $[4,5,8,11,15]$; not surprisingly, radioimmunoassay analysis of neurointermediate lobes of these species show that desacetyl- $\alpha$ MSH makes only a very minor contribution of acetylated forms of this peptide $[2,6$, $11,12,22]$. Goldman and Loh [7] have recently suggested that the major route for acetylation of MSH in the intermediate lobe of Xenopus laevis is comparable to the situation in mammals. In our opinion, the fact that desacetyl- $\alpha \mathrm{MSH}$ is the major intracellular form of MSH in Xenopus makes such a comparison untenable.

As expected for a secretory process, the release of immunoreactive MSH from superfused melanotropes was found to be $\mathrm{Ca}^{2+}$-dependent. The finding that high $\mathrm{K}^{+}$in the superfusion medium leads to a stimulation of the release of MSH was to be expected in that $\mathrm{K}^{+}$depolarizes cell membranes. More interesting is the response of intact tissue to high $\mathrm{K}^{+}$, namely a complete inhibition of the secretion process. In that intact neurointermediate lobe tissue is rich in nerve terminals $[3,9,20,24,25,29]$, a good assumption is that high $\mathrm{K}^{+}$induces secretion of a factor or factors from these terminals which subsequently inhibit MSH secretion from the melanotrope. Indeed, we have found that high $\mathrm{K}^{+}$ stimulates release of both dopamine and GABA from nerve terminals within the neurointermediate lobe tissue (unpublished observation). In view of the presence of at least these two inhibitory neurotransmitter systems within this tissue, it is not surprising that the dopamine receptor antagonist sulpiride failed to antagonize the $\mathrm{K}^{+}$induced inhibition of MSH-secretion. An important conclusion we can draw from the results with high $\mathbf{K}^{+}$is that the isolated melanotropes appear to be free of any interfering nerve terminals. Therefore, in our subsequent studies with these cells we consider that any effect of secretagogues on release of MSH from the superfused melanotropes is due to a direct action of the secretagogues on the melanotropes themselves.

Dopamine is an important MSH-inhibiting factor in both mammals and sub-mammalian species [1]. For Xenopus laevis it has been shown that this neurotransmitter is extremely potent in inhibiting release of both $\mathrm{MSH}[10,14]$ and other POMC-related peptides [13,17]. All these studies have been conducted with intact neurointermediate lobe tissue. The present results establish that, in inducing inhibition of MSH release, dopamine acts directly on the melanotrope 
cell. The observation that sulpiride, a specific D2 receptor antagonist, could reverse the dopamine induced inhibition indicates that Xenopus melanotropes possess dopamine receptors of the D2 type.

There are recent indications that the neurotransmitter GABA may also be of general importance as an MSH secretagogue. A GABAergic fiber network has been found throughout the pars intermedia of both the rat $[21,31]$ and toad Xenopus laevis [29] and GABA has been shown to affect secretion of MSH in these species $[26,29]$. The response of Xenopus neurointermediate lobes to exogenous GABA is a very rapid inhibition of secretion of immunoreactive MSH [29]. Subsequent receptor characterization has shown that the Xenopus neurointermediate lobe tissue contains both GABAa and GABAb receptors. Activation of either of these receptors induces inhibition of in vitro MSH secretion
[30]. It is apparent from the present results that the Xenopus laevis melanotrope cell itself possesses both the GABAa and the GABAb receptor. Receptor localization at the ultrastructural level will have to resolve whether independent GABAergic neuronal systems exist to independently utilize these two receptor mechanisms.

\section{ACKNOWLEDGEMENTS}

The authors wish to thank Drs. R. de Leeuw and H. Goos (University of Utrecht, The Netherlands) for their advice in preparing cell suspensions; Dr. H. Vaudry (University of Rouen, France) for providing the antiserum; Mr. T. Ayoubi and Mr. P. M. J. M. Cruysen for technical assistance; Mr. R. E. Engels for the animal care; and Mrs. L. Jansen-Hoorweg for secretarial assistance.

\section{REFERENCES}

1. Bagnara, J. T. and M. E. Hadley. Chromatophores and Color Change: The Comparative Physiology of Animal Pigmentation. Englewood Cliffs, NJ: Prentice Hall, 1973.

2. Browne, C. A., H. P. J. Bennett and S. Solomon. Isolation and characterization of corticotropin- and melanotropin-related peptides from the neurointermediate lobe of the rat pituitary by reversed-phase liquid chromatography. Biochemistry 20: 45384546, 1981.

3. DeVolcanes, B. and B. Weatherhead. Stereological analysis of the effects of 6-hydroxydopamine on the ultrastructure of the melanocyte-stimulating hormone cell of the pars intermedia of the pituitary of Xenopus laevis. Gen Comp Endocrinol 28: 205$212,1976$.

4. Eipper, B. A. and R. E. Mains. Existence of a common precursor to ACTH and endorphin in the anterior and intermediate lobes of the rat pituitary. $J$ Supramol Struct 8: 247-262, 1978.

5. Eipper, B. A. and R. E. Mains. Structure and biosynthesis of pro-adrenocorticotropin/endorphin and related peptides. Endocr Rev 1: 1-27, 1980.

6. Goldman, M. E., M. Beaulieu, J. W. Kebabian and R. L. Eskay. $\alpha$-Melanocyte-stimulating hormone-like peptides in the intermediate lobe of the rat pituitary gland: Characterization of content and release in vitro. Endocrinology 112: 435-441, 1983.

7. Goldman, M. E. and Y. P. Loh. Intracellular acetylation of desacetyl $\alpha$-MSH in the Xenopus laevis neurointermediate lobe. Peptides 5: 1129-1134, 1984.

8. Herbert, E. Discovery of pro-opiomelanocortin. A cellular polyprotein. Trends Biochem Sci 6: 184-188, 1980.

9. Hopkins, C. R. Localization of adrenergic fibers in the amphibian pars intermedia by electron microscope autoradiography and their selective removal by 6 -hydroxydopamine. Gen Comp Endocrinol 16: 112-120, 1971.

10. Jenks, B. G. Control of MSH synthesis and release in the aquatic toad Xenopus laevis. In: Frontiers in Hormone Research, edited by $\mathrm{Tj}$. van Wimersma Greidanus. Basel: Karger, 1977, pp. 63-65.

11. Jenks, B. G., J. H. H. N. van Daal, J. G. M. Scharenberg, G. J. M. Martens and A. P. van Overbeeke. Biosynthesis of proopiomelanocortin-derived peptides in the mouse neurointermediate lobe. J Endocrinol 98: 19-34, 1983.

12. Leenders, H. J., J. J. W. Janssens, H. J. M. Theunissen, B. G. Jenks and A. P. van Overbeeke. Acetylation of melanocytestimulating hormone and $\beta$-endorphin in the pars intermedia of the perinatal pituitary gland in the mouse. Neuroendocrinology, in press.

13. Loh, Y. P. and H. Gainer. Biosynthesis, processing and control of release of melanotropic peptides in the neurointermediate lobe of Xenopus laevis. J Gen Physiol 70: 37-58, 1977.
14. Loh, Y. P., A. Li, H. A. Gritsch and R. L. Eskay. Immunoreactive $\alpha$-melanotropin and $\beta$-endorphin in the toad pars intermedia: dissociation in storage, secretion and subcellular localization. Life Sci 29: 1599-1605, 1981.

15. Mains, R. E. and B. A. Eipper. Biosynthetic studies on ACTH, $\beta$-endorphin and $\alpha$-melanotropin in the rat. Proc Natl Acad Sci USA 343: 94-110, 1980.

16. Martens, G. J. M., O. Civelli and E. Herbert. Nucleotide sequence of c-DNA for pro-opiomelanocortin in the amphibian Xenopus laevis. J Biol Chem 261: 13685-13689, 1985.

17. Martens, G. J. M., B. G. Jenks and A. P. van Overbeeke. Microsuperfusion of neurointermediate lobes of Xenopus laevis: Concomitant and coordinately controlled release of newly synthesized peptides. Comp Biochem Physiol [C] 69: 75-82, 1981.

18. Martens, G. J. M., B. G. Jenks and A. P. van Overbeeke. N$\alpha$-acetylation is linked to $\alpha$-MSH release from pars intermedia of the amphibian pituitary gland. Nature 294: 558-560, 1981.

19. Martens, G. J. M., B. G. Jenks and A. P. van Overbeeke. Biosynthesis of pairs of peptides related to melanotropin, corticotropin, and endorphin in the pars intermedia of the amphibian pituitary gland. Eur I Biochem 122: 1-10, 1982.

20. Nakai, Y. and A. Gorbman. Evidence for a doubly innervated secretory unit in the anuran pars intermedia. II: electron microscopic studies. Gen Comp Endocrinol 13: 108-116, 1969.

21. Oertel, W. H., E. Mugnaini, M. L. Tappaz, V. K. Weise, A. L. Dahl, E. E. Schmechel and 1. J. Kopin. Central GABAergic innervation of neurointermediate pituitary lobe-biochemical and immunocytochemical study in the rat. Proc Natl Acad Sci USA 79: 657-679, 1982.

22. Rudman, D., R. K. Chawla and B. M. Hollins. N,O-diacetylserine- $\alpha$-melanocyte stimulating hormone, a naturally occurring melanotropic peptide. J Biol Chem 254: 10102-10108, 1979.

23. Sharman, D. F., P. Holzbauer and M. Holzbauer. In vitro release of endogenous catecholamines from the neural and intermediate lobe of the pituitary. Neuroendocrinology 34: 175-179, 1982.

24. Terlou, M. and H. W. M. van Straaten. The development of a hypothalamic monoaminergic system for the regulation of pars intermedia activity in Xenopus laevis. $Z$ Zellforsch 143: 229 $238,1973$.

25. Terlou, M., H. J. Th. Goos and P. G. W. J. van Oordt. Hypothalamic regulation of pars intermedia activity in amphibians. Fortschr Zool 22: 117-134, 1974.

26. Tomiko, S. A., P. S. Taraskevich and W. W. Douglas. GABA acts directly on cells of pituitary pars intermedia to alter hormone output. Nature 301: 706-707, 1983.

27. Vaudry, H. M. C. Tonon, C. Delarue, R. Vaillant and J. Kracier. Biological and radioimmunological evidence for melanocyte-stimulating hormones (MSH) of extrapituitary origin in the rat brain. Neuroendocrinology 27: $2-24,1978$. 
28. Verburg-van Kemenade, B. M. L., B. G. Jenks and A. P. van Overbeeke. Regulation of melanotropin release from the pars intermedia of the amphibian Xenopus laevis: evaluation of the involvement of serotonergic, cholinergic or adrenergic receptor mechanisms. Gen Comp Endocrinol 63: 471-480, 1986.

29. Verburg-van Kemenade, B. M. L., M. Tappaz, L. Paut and B G. Jenks. Gabaergic regulation of melanocyte-stimulating hormone from the pars intermedia of Xenopus laevis: Immunocytochemical and physiological evidence. Endecrinology 118: 260-267, 1986.
30. Verburg-van Kemenade. B. M. L., B. G. Jenks, F. Y. A. Lenssen and $\mathrm{H}$. Vaudry. Characterization of $\mathrm{GABA}$ receptors in the neurointermediate lobe of the amphibian Xenopus laevis. Endocrinology, in press.

31. Vincent, S. R., T. Hokfelt and J. Y. Wer. GABA neuron system in hypothalamus and pituitary gland; immunohistochemical demonstration using antibodies against glutamate decarboxylase. Neuroendocrinology 34: 117-125, 1982. 